Galbraith, D. (1999) Writing as a knowledge constituting process. In M.Torrance and D. Galbraith (eds.), Knowing What to Write: Conceptual Processes in Text Production, pp. 139-160. Amsterdam: Amsterdam University Press.

Greenlaw, S. A. (2003) Using writing to enhance student learning in undergraduate economics, International Review of Economics Education, 1, 61-70.

Guest, R. and Vecchio, N. (2003) Are There Learning Spillovers in Introductory Macroeconomics, International Review of Economics Education 1, 36-60.

Haberler, G. (1936) The Theory of International Trade. London:William Hodge.

Halldén, O., Scheja, M. and Haglund, L. (2008) The contextuality of knowledge: an intentional approach to meaning making and conceptual change. In S. Vosniadou (Ed.) Handbook of Research on Conceptual Change. Hillsdale: Erlbaum.

Hay, D. and Kinchin, I. (2005) The evolution of a collaborative concept mapping activity for undergraduate microbiology students, Journal of Further and Higher Education, 29,1 pp. 1-14.

Land, R., Meyer, J.H.F. and Smith, J. (2008) (Eds) Threshold Concepts within the Disciplines. Rotterdam: Sense Publishers.

Lerner, A. (1932). The Diagrammatical Representation of Cost Conditions in International Trade, Economica, 37, pp. 346-356.

Martell, K., Navin, J. and Sullivan, T. (2006) 'Teaching College Economics in a High School Setting: Lessons Learned and Implementation Strategies', International Review of Economics Education, 5, 1, 9-27.

Meyer, J.H.F. and Land, R. (2003) Threshold concepts and troublesome knowledge: linkages to ways of thinking and practising within the disciplines. In C. Rust (Ed.) Improving Student Learning. Improving Student Learning Theory and Practice - 10 years on. pp. 412-424. Oxford: OCSLD.

Meyer, J.H.F. and Land, R. (2005) Threshold concepts and troublesome knowledge (2): epistemological considerations and a conceptual framework for teaching and learning. Higher Education. 49, 3, pp. 373-388.

Perkins, D. (2006) Constructivism and Troublesome Knowledge. In J.H.F Meyer and R. Land (Eds) Overcoming Barriers to student understanding:Threshold concepts and troublesome knowledge. London: Routledge.

Shanahan, M., Foster, G. and Meyer, J.H.F. (2006) Operationalising a Threshold Concept in Economics: A Pilot Study Using Multiple Choice Questions on Opportunity Cost, International Review of Economics Education, 5, 2, pp. 29-57.

Shanahan, M., Foster, G. and Meyer, J.H.F. (2008) Associations Between Prior Acquisition of Threshold Concepts, Learning Dimensions and Examination Performance in First-Year

Economics. In Land, R., Meyer, J.H.F. and Smith, J. (Eds) Threshold Concepts within the Disciplines, pp. 37-50. Rotterdam: Sense Publishers.

Sinatra, G. M. and Pintrich, P.R. (2003) (Eds.) Intentional Conceptual Change, New York: Lawrence Erlbaum Associates.

Trautwein, U. and Ludtke, O. (2007) Epistemological beliefs, school achievement, and college major: A large-scale longitudinal study on the impact of certainty beliefs, Contemporary Educational Psychology, 32, pp. 348-366.

Von Wieser, F. (1891) The Austrian School and the Theory of Value, Economic Journal 1, pp. 108-121.

\section{Political Orientation and the Decision to Major in Economics: Some Preliminary Observations}

Robin L. Bartlett, Marianne A. Ferber and Carole A. Green

\section{Abstract}

Studies find that students major in economics for a variety of reasons. None, however, have examined students' political orientations as a possible factor in their choice of majors. Economics, as compared to other social sciences, tends to produce conservative policy recommendations. This pilot study explores whether more conservative students are attracted to economics. Our study found that men with conservative political leanings are more likely to major in economics and that male students in economics are more conservative than female students. Political orientation, however, does not appear to be a significant factor in the choice of a major for women.

\section{Introduction}

It is well documented that students who major in disciplines that continue to be male-dominated earn a premium on their investment (Arcidiacono, 2004; Black, Sanders and Taylor, 2003; Daymont and Andrisani, 1984; Weinberger, 1999) and economics is, of course, one of these disciplines. However, the trend in the percentage ${ }^{1}$ of undergraduate degrees earned in economics in the USA has for some time been negative, sliding from 6.4 per cent in 1970 to 5.4 per cent in 2003. During those years there were some ups and downs, but a smaller percentage of undergraduates choose economics as a major now than at the beginning of this period. Further, while the percentage of women receiving undergraduate degrees in economics from all institutions in the USA grew from 25 per cent in 1975 to 35 per cent in 1985, it fell to 30 per cent by 1990 and since then has hovered around 
30-32 per cent (Siegfried and Scott, 1994; Siegfried, 2008).2 Similarly unbalanced percentages have been found in other countries. For example, Jonung and Ståhlberg (2007) reported that among upper-level undergraduates in Sweden only one third are women. ${ }^{3}$ The low percentage in the USA is particularly discouraging in light of the fact that since 1985 the proportion of women earning BAs in all fields has increased from 55 to 60 per cent. Thus the decline in economics is in stark contrast to other fields and shows that economics is failing to attract a proportionate share of female students.

Following Kemmelmeier, Danielson and Basten (2005) who found that students are more inclined to choose fields that have a political orientation consistent with their own, we use data from a survey of first and third year students at Denison University, a small liberal arts university in the mid-western part of the USA, to further investigate the relationship between political leanings, gender and the decision to major in economics. Denison University is representative of the top liberal arts colleges in the country, where a significantly higher proportion of undergraduates major in economics than in the large public and private institutions.

\section{Sex segregation in majors}

Table 1 shows the percentage of BA degrees earned by women in four selected majors and three broader fields in the USA between 1970 and 2003. The data clearly show that economics consistently not only has a smaller proportion of women than all undergraduate fields combined but also than all social sciences. In fact, the figures for the social sciences would even be considerably higher than those shown if economics were excluded, and are much higher in the relatively closely related disciplines of political science and sociology. Moreover, between 1985 and 2003, the per cent of BAs in the social sciences earned by women increased from 44.1 to 51.8 per cent while in economics it remained virtually unchanged at 34 per cent. 4

A recent paper by England and Li (2006) found that while the Duncan index of segregation (DIS) 5 for the distribution of undergraduate majors by gender has decreased over the past 30 years, most of the change occurred from 1975 to 1985 The stagnation after that apparently has been the result of women continuing to move into traditionally male majors, while the proportion of men in these fields remained stable or even decreased, thus in some instances tipping the balance toward women, as occurred, for example, in communications and psychology. The failure of the percentage of women earning bachelors degrees in economics to increase to any extent over the past 30 years as compared with the movement of
Table 1: Percentage of BA degrees earned by women in selected disciplines in the United States: 1970-2003

\begin{tabular}{|c|c|c|c|c|c|c|c|c|}
\hline Year & Sociology & Economics & $\begin{array}{l}\text { Political } \\
\text { Science }\end{array}$ & Psychology & $\begin{array}{l}\text { Social } \\
\text { Science }\end{array}$ & $\begin{array}{l}\text { Physical } \\
\text { Sciences }\end{array}$ & $\begin{array}{c}\text { Life } \\
\text { Sciences }\end{array}$ & $\begin{array}{l}\text { All } \\
\text { BAs }\end{array}$ \\
\hline $1970-74$ & 57.9 & 13.9 & 21.9 & 48.3 & 36.5 & 15.6 & 25.0 & 44.5 \\
\hline $1975-79$ & 57.9 & 25.0 & 33.3 & 59.0 & 40.6 & 21.3 & 33.1 & 50.3 \\
\hline $1980-84$ & 61.3 & 33.0 & 48.1 & 67.1 & 44.3 & 26.6 & 42.1 & 54.9 \\
\hline $1985-89$ & 68.7 & 33.0 & 53.8 & 70.1 & 44.1 & 29.5 & 46.4 & 56.8 \\
\hline 1990-94 & 68.8 & 30.1 & 55.3 & 73.0 & 45.9 & 33.0 & 48.8 & 59.1 \\
\hline 1995-99 & 68.4 & 31.5 & 64.9 & 74.6 & 49.5 & 38.4 & 52.1 & 60.7 \\
\hline 2000-03 & 70.4 & 34.0 & 70.1 & 77.6 & 51.8 & 41.5 & 60.7 & 60.0 \\
\hline
\end{tabular}

Source: Digest of Educational Statistics. 2004. Calculated from Table 247.'Earned degrees conferred by degree-granting institutions, by level of degree and sex of student: 1969-70 to 2003-04.'

women into other 'non-traditional fields,' including even the physical sciences and mathematics, is worthy of attention.

\section{Determinants of students' choices of major}

From the literature

Studies attempting to determine how students decide whether to major in economics have frequently focused on male/female differences in innate abilities, interest in the subject, gender roles, and career opportunities in the field, 6 while few have examined the relevance of the learning environment. Among those who have addressed this issue, Feiner (1993) also concluded that women might not find many topics in basic economics courses of interest to them. A number of others have suggested that women may be at a disadvantage because they prefer more active and cooperative teaching techniques to those used in most economics classrooms (Colbeck, Cabrera and Terenzini, 2001; Hativa and Birenbaum, 2000; Philbin and Meier, 1995), although some researchers found that women do not mind lectures any more than men do (Jensen and Owen, 2001). Some found that role models were not an important factor in whether women choose to major in economics (Ehrenberg, Goldhaber and Brewer, 1995; Robb and Robb, 1999; Swope and Schmitt, 2006) while others reached the opposite conclusion (Rask and Bailey, 2002, Rothstein 1995). 7 In any case, however, the bottom line is that women do not perform as well in their economics courses as they do in others (Jensen and Owen, 
2001), 8 while the opposite is true of men. All else equal, a student is far more likely to continue in a field where $s /$ he has a comparative advantage (i.e. where $s /$ he is likely to rank more highly as compared to the other students in that field).

\section{Policy orientation}

Although many researchers have examined possible causes for the low representation of women among undergraduate economics majors, that the imbalance may have its roots in relatively too many men being attracted to the major, seems to have escaped their notice. Likewise, none have considered the likely role of the fact that economics is the one discipline where, along with courses generally only taught in business schools, conservatives have a slight edge in obtaining higher grades (Kemmelmeier, Danielson and Basten, 2005). The reason may be that in many such classes, anyone who questions whether rapid growth of income is really more important than how it is distributed, or who argues that government has a useful role to play as a referee, an enforcer or a provider of public goods, is looked upon askance, because the instructors believe that markets left to themselves provide the best answer to the crucial economic questions of what should be produced, as well as how and for whom. ${ }^{9}$ Most economics instructors today tend to be profoundly conservative, and especially so in the USA.10

To the extent that instructors in the USA, whether in introductory or advanced economics courses, have been teaching this version of conservative neoclassical, or 'positive' economics, many students with an interest in economics but more liberal leanings may feel awkward about speaking out and engaging in discussion with such an instructor or their classmates, and are likely not to perform as well as they would in an environment that 'fits' them better (Porter and Umbach, 2006). Some may therefore decide to explore other majors that are also to some extent concerned with economic issues, such as political science or sociology, while students with more conservative leanings would be more likely to remain in economics. ${ }^{11}$

\section{A pilot study}

\section{The sample}

As previously noted, Denison University, a small liberal arts university 12 in the USA, is the source of the data for this study. As a final class assignment in an honours course, Women and the US Economy:The Case of the Economics Profession, in the fall of 2004, students were given selections from the literature on choosing a major and then asked to use that information to design a questionnaire to be sent to all first and third year students to test the conclusions in the literature concerning this decision. The freshmen were selected because they were probably just beginning to think about choosing their major and the juniors, because they had just recently declared their major.

Questionnaires were e-mailed twice in November.13 There were 215 usable responses; the proportion of men and women and their majors were representative of those of the student population at Denison. The number of responses was sufficient to obtain meaningful results by running regressions, 14 the results of which are reported below. Since, as mentioned above, the percentage of men and women majoring in economics at Denison has mirrored the national trend in small liberal arts colleges and universities, our sample appears to be representative of the general economics population in such institutions. There may, however, be differences between students at these schools and those at large Ph.D.-granting institutions. Therefore our results may not be applicable even to all universities in the USA. They do, however, provide a useful basis for a large-scale study that might help us find answers to the troubling question of the under-representation of women in economics. 15

\section{Data and methodology}

Political views, gender, and major

In the questionnaire, students were asked to indicate whether their political orientation could be described as far left (extremely liberal), left (liberal), moderate, right (conservative), or far right (extremely conservative). Forty-six per cent reported that they were left or far left, 35 per cent that they were moderate, and 19 per cent that they were right or far right. 16 Table 2 shows the breakdown by gender. Although there is substantial evidence that women tend to be more liberal than men (Abrams and Settle, 1999; Ferber and Brün, 2006; Lott and Kenny, 1999), among these students nearly half of both males and females consider themselves to be liberal or very liberal; however, 39 per cent of women and 30 per cent of men consider themselves moderates and only 15 per cent of women as compared to 25 per cent of men claim to be conservatives. ${ }^{17}$

Table 3 shows the relationship between political leanings and major. Although the sample sizes are too small to reach statistically significant conclusions, there appears to be a tendency for those of different political inclinations to choose different majors. For example, in our survey no conservative students are majoring in either the arts or in interdisciplinary studies while 65 per cent and 70 per cent of students majoring in these fields, respectively, describe themselves as liberal. In both the social sciences (excluding economics) and economics the largest proportions of majors are conservatives, 32 and 34 per cent, respectively. The largest percentage of moderates is found in the social sciences. 
Table 2: Relationship between gender and political views

\begin{tabular}{lccc}
\hline \multirow{2}{*}{ Politics } & \multicolumn{2}{c}{ Gender } & \\
\hline Liberal or Very liberal & 41 & Females & Total \\
Moderate & $(45 \%)$ & $(46 \%)$ & $46 \%$ \\
Conservative or Very conservative & 28 & 48 & $35 \%$ \\
Total & $(30 \%)$ & $(39 \%)$ & \\
\hline & $(25 \%)$ & 18 & $19 \%$ \\
& 92 & 123 & 215 \\
\hline
\end{tabular}

Table 3: Relationship between major and political views

\begin{tabular}{|c|c|c|c|c|c|c|c|c|}
\hline Politics & $\begin{array}{r}\text { Science } \\
\text { Ec }\end{array}$ & $\begin{array}{l}\text { Social H } \\
\text { Science } \\
\text { (except } \\
\text { conomics) }\end{array}$ & $\begin{array}{l}\text { Humanities } \\
\text { s) }\end{array}$ & $\begin{array}{l}\text { Major } \\
\text { Arts }\end{array}$ & $\begin{array}{l}\text { Inter- } \\
\text { lisciplina }\end{array}$ & $\begin{array}{l}\text { Undecided } \\
y\end{array}$ & Economics & Total \\
\hline $\begin{array}{l}\text { Liberal or } \\
\text { Very liberal }\end{array}$ & $\begin{array}{c}23 \\
(48 \%)\end{array}$ & $\begin{array}{c}6 \\
(24 \%)\end{array}$ & $\begin{array}{c}25 \\
(52 \%)\end{array}$ & $\begin{array}{c}11 \\
(65 \%)\end{array}$ & $\begin{array}{c}14 \\
(70 \%)\end{array}$ & $\begin{array}{c}6 \\
(46 \%)\end{array}$ & $\begin{array}{c}13 \\
(30 \%)\end{array}$ & $46 \%$ \\
\hline Moderate & $\begin{array}{c}18 \\
(37.5 \%)\end{array}$ & $\begin{array}{c}11 \\
(44 \%)\end{array}$ & $\begin{array}{c}13 \\
(27 \%)\end{array}$ & $\begin{array}{c}6 \\
(35 \%)\end{array}$ & $\begin{array}{c}6 \\
(30 \%)\end{array}$ & $\begin{array}{c}6 \\
(46 \%)\end{array}$ & $\begin{array}{c}16 \\
(36 \%)\end{array}$ & $35 \%$ \\
\hline $\begin{array}{l}\text { Conservative } \\
\text { or Very } \\
\text { conservative }\end{array}$ & $\begin{array}{c}7 \\
(15 \%)\end{array}$ & $\begin{array}{c}8 \\
(32 \%)\end{array}$ & $\begin{array}{c}10 \\
(21 \%)\end{array}$ & $\begin{array}{c}0 \\
(0 \%)\end{array}$ & $\begin{array}{c}0 \\
(0 \%)\end{array}$ & $\begin{array}{c}1 \\
(7 \%)\end{array}$ & $\begin{array}{c}15 \\
(34 \%)\end{array}$ & $19 \%$ \\
\hline Total & 48 & 25 & 48 & 17 & 20 & 13 & 44 & 215 \\
\hline
\end{tabular}

However, the data shown in Table 3, although informative, do not tell the whole story, for they combine male and female students. As can be seen in Table 4, political views also differ by gender.

Parts a to $c$ in Table 4 show the relationships between political views and gender among majors in science, social science (excluding economics) and economics. Again, the results are suggestive. In Table $4 a$, we see that male science majors are overwhelmingly liberal, whereas their female counterparts are more likely to be moderate in their political views. Among social science majors (Table 4b), nearly half of women students are moderates and fewer than 30 per cent are conservatives; among male students, moderates and conservatives each are 37.5
Table 4a: Relationship between gender and political views among science majors

\begin{tabular}{|c|c|c|c|}
\hline \multirow[b]{2}{*}{ Politics } & \multicolumn{2}{|c|}{ Gender } & \multirow[b]{2}{*}{ Total } \\
\hline & Males & Females & \\
\hline Liberal or Very liberal & $\begin{array}{c}13 \\
(62 \%)\end{array}$ & $\begin{array}{c}10 \\
(37 \%)\end{array}$ & $48 \%$ \\
\hline Moderate & $\begin{array}{c}6 \\
(29 \%)\end{array}$ & $\begin{array}{c}12 \\
(44 \%)\end{array}$ & $37 \%$ \\
\hline Conservative or Very conservative & $\begin{array}{c}2 \\
(10 \%)\end{array}$ & $\begin{array}{c}5 \\
(19 \%)\end{array}$ & $15 \%$ \\
\hline Total & 21 & 27 & 48 \\
\hline
\end{tabular}

Table 4b: Relationship between gender and political views among social science majors (excluding economics)

\begin{tabular}{lccc}
\hline \multirow{2}{*}{ Politics } & \multicolumn{2}{c}{ Gender } & \\
\hline Liberal or Very liberal & 2 & Females & Total \\
Moderate & $(25 \%)$ & $(24 \%)$ & $24 \%$ \\
Conservative or Very conservative & 3 & 8 & \\
& $(37.5 \%)$ & $(47 \%)$ & $44 \%$ \\
Total & 3 & 5 & $32 \%$ \\
\hline
\end{tabular}

Table 4c: Relationship between gender and political views among economics majors

\begin{tabular}{lccc}
\hline \multirow{2}{*}{ Politics } & \multicolumn{2}{c}{ Gender } & \\
\hline Liberal or Very liberal & 6 & Females & Total \\
Moderate & $(19 \%)$ & $(58 \%)$ & $30 \%$ \\
Conservative or Very conservative & 12 & 4 & $36 \%$ \\
Total & $(37.5 \%)$ & $(33 \%)$ & \\
\hline
\end{tabular}


per cent. Table 4c shows that among both economics and science majors there are considerable differences between men and women: only 19 per cent of male but 58 per cent of female economics majors are liberal while 44 per cent of male students are conservative, compared with only 8 per cent of female students. Whether similar results would be found in other countries is a matter for conjecture. Monteiro and Lopes (2007) report considerable differences in electives available to students majoring in economics in the UK and some other European countries compared to those offered in the USA, but whether this additional freedom of choice would have any impact on the distribution of economics majors by gender is difficult to say. In any case, the results reported above suggest that different factors attract women to a major than those that attract male students.

\section{Regression analysis}

We now turn to regression analysis, specifically, binomial logit models, to gain more insights about economics majors. In all of the regressions the dependent variable is whether or not the individual is an economics major. In Model 1 we examine all students together using a gender dummy variable. In Models 2 and 3 we analyse men and women students separately since a likelihood ratio test (the counterpart to a Chow Test used to test for the equality of two regression equations) showed with a 95 per cent level of significance that separate equations are required.

The independent variable central to the focus of our paper measures political orientation on a scale of -2 (very liberal) to +2 (very conservative), with a value of zero indicating moderate views. Our hypothesis is that the coefficient for this variable will be positive, indicating that conservative students are more likely to major in economics. ${ }^{18}$

The variables derived from the questions asked about the importance of various factors in influencing the choice of college major are measured on a scale of 1 to 6 , where a value of 6 indicates 'very influential' and 1 means 'not at all influential'. The first of these variables is 'Career options with that major'. We hypothesise that the coefficient on this variable will be positive since those who consider career options as important are likely to view economics as a gateway to many occupational choices. ${ }^{19} \mathrm{~A}$ second variable used in the regression is 'High school classes'. Students who rank this factor as influential and had a positive experience in a high school economics course would be expected to be more likely to major in economics. On the other hand, not all high school students have the opportunity to take an economics class, and some of those who did take one may not have found it a positive experience. Hence it is not possible to predict the sign on this variable. The third factor we included is 'College courses. It is clear that a student's choice of major would be positively influenced by college courses $s$ /he found interesting. In the case of economics, college courses are likely to be particularly important since, as noted above, not all students study economics in high school. We expect the sign on this variable to be positive for students who found their economics courses interesting. The last factor incorporated into our regression equations is ' $\mathrm{Classroom}$ environment'. As discussed above, economics classes tend to be rather competitive. Because many students do not find this type of environment congenial, those who consider this factor important would be expected to be less likely to major in economics. Thus, we anticipate a negative sign on this variable.

Two variables in our models pertain to mathematics. Students were asked to rate their math ability compared to that of their peers at Denison on a 5-point scale, coded from +2 when they considered themselves higher than 90 per cent of their peers, to -2 when they considered themselves below 90 per cent of their peers. Since mathematics has become an integral part of economics, those who consider themselves above average in this respect may be expected to be more likely to major in economics than students who have less confidence in their mathematical skills. 20 The second math-related variable indicates the highest level of math the student believes is required to major in economics on a scale of 1 to 6 with Algebra II being 1 and 'More than linear algebra' being number 6.21 Because it is likely that those believing that higher levels of math are required will be less likely to major in economics, we expect a negative sign on this variable. 22

There were also questions in the survey that pertain to the student's mother's occupation. We included in our model a dummy variable indicating whether or not the mother is in a traditionally male occupation.23 Our hypothesis is that female students whose mothers are engaged in such occupations will be more likely to major in economics, so that this variable is expected to have a positive sign. Finally, a gender dummy variable is included in Model 1 to measure the effect gender may have on the choice of economics as a major, independent of the factors accounted for by the other variables. ${ }^{24}$ The coefficient on this variable will be positive and significant if the other variables do not fully account for the difference between men and women.

Table 5 shows the means or proportions of the variables used in the regression equations; those where differences between male and female students are statistically significant are indicated by a superscript $d$. Forty-four per cent of the students in the sample are male; 21 per cent are economics majors. Somewhat more than half of the students are on the liberal side of the political spectrum, women slightly more so than men. Of the four factors influencing the choice of major, college courses are the most important, and high school courses the least important. Students as a whole rated themselves slightly higher than average in 
Table 5: Means of variables used in the regression equations

\begin{tabular}{lccc}
\hline Variables & All & $\begin{array}{c}\text { Group } \\
\text { Males }\end{array}$ & Females \\
\hline Male & 0.444 & - & - \\
Conservative political orientation & -0.357 & -0.310 & -0.394 \\
& $(0.984)$ & $(1.038)$ & $(0.943)$ \\
Mother in non-traditional occupation & 0.423 & 0.483 & 0.376 \\
(Dummy variable) & & & \\
Self-rated math abilitya & 0.097 & 0.299 & $-0.064 \mathrm{~d}$ \\
& $(0.920)$ & $(0.978)$ & $(0.842)$ \\
Importance of factors influencing choice of majorb & & \\
Career opportunities & 4.566 & 4.552 & 4.578 \\
& $(1.425)$ & $(1.461)$ & $(1.403)$ \\
High school course(s) & 3.617 & 3.563 & 3.661 \\
& $(1.582)$ & $(1.553)$ & $(1.611)$ \\
College course(s) & 4.888 & 4.793 & 4.963 \\
& $(1.136)$ & $(1.013)$ & $(1.224)$ \\
Classroom environment & 4.046 & 3.989 & 4.092 \\
& $(1.270)$ & $(1.298)$ & $(1.251)$ \\
Perceived level of math required to & 3.464 & 3.161 & $3.706 \mathrm{~d}$ \\
major in economicsc & $(1.262)$ & $(1.219)$ & $(1.249)$ \\
Economics major & 0.209 & 0.345 & $0.101 \mathrm{~d}$ \\
$N$ & 196 & 87 & 109 \\
\hline
\end{tabular}

Notes: Standard deviations are shown in parentheses where applicable.

a Positive (negative) values indicate above (below) average of peers.

b The importance of these factors was ranked on a scale of 1 to 6 with higher values indicating greater importance.

c Values range from 1 to 6 where $1=$ Algebra II and $6=$ 'more than Linear Algebra'.

d Mean or proportion is significantly different from that of male students at a $5 \%$ level of significance.

mathematical ability 25 and believed that at least one calculus course was required to major in economics. Over 40 per cent reported that their mothers were engaged in occupations that have not traditionally been held by women.

This table shows several significant differences between male and female students. First, the percentage of male students majoring in economics is 34 per cent compared to 10 per cent of female students. Second, women ranked themselves significantly lower in mathematical ability than did men (despite the fact that they reported significantly higher GPAs) and believed that significantly higher levels of maths were required to major in economics. Finally, and perhaps surprisingly, women students were less likely than male students to have mothers in non-traditional occupations. Another difference, not statistically significant, but nonetheless interesting, is that the classroom environment was rated as being more influential in the choice of major by female than by male students.

One additional econometric issue that might be raised, related to the discussion earlier in the paper, is that of endogeneity, i.e.'does the causality run in both directions?' Since there were two classes of students in the sample, freshmen and juniors, we tested for significant differences in the means of the political orientation variable and the 'career options' variable between the two groups. If there were endogeneity, we would expect that the juniors (presumably having had more economics classes) would be more conservative and would rank career options as more influential. We did not, however, find any significant differences between the two groups. 26

\section{Regression results}

Table 6 shows the results of the three regression equations using the responses of 196 students for whom all the variables are available. Although, as discussed above, separate equations by gender are appropriate, it is interesting to first examine Column 1 that shows the results of the model using the entire sample with a gender dummy variable. As expected, ceteris paribus, male students are found to be significantly more likely to major in economics than are female students. Turning next to the results at the heart of our paper, we see that political orientation does appear to play an important role in the decision to major in economics: being conservative or highly conservative significantly increases the likelihood that a student will major in economics. However, running the same regression with an interaction term between being male and political orientation indicates that it is significant only because of the male students in the sample. For women, the variable has a negative sign but is not significant.

As for the other explanatory variables, only two of the four factors that students could rate as influencing their choice of major are significant in our model: those who ranked career opportunities as an important factor were considerably more likely to choose economics as a major; and those who rated having had a high school course as highly influential were substantially less likely to do so.27 
Table 6: Results of binomial logit regression equations

\begin{tabular}{lccc}
\hline Variables & All & $\begin{array}{c}\text { Group } \\
\text { Males }\end{array}$ & Females \\
\hline Male & $1.521^{* * *}$ & - & - \\
& $(0.488)$ & & \\
Conservative political orientation & $0.546^{* *}$ & $0.865^{* * *}$ & 0.079 \\
& $(0.252)$ & $(0.315)$ & $(0.541)$ \\
Mother in non-traditional occupation & $0.748^{*}$ & 0.428 & 1.354 \\
& $(0.451)$ & $(0.554)$ & $(0.871)$ \\
Self-rated math abilitya & $0.806^{* * *}$ & 0.419 & $1.484^{* * *}$ \\
& $(0.268)$ & $(0.322)$ & $(0.549)$ \\
Factors influencing choice of majorb & & & \\
Career opportunities & $0.620^{* * *}$ & $0.456^{* *}$ & $0.841^{*}$ \\
& $(0.198)$ & $(0.230)$ & $(0.495)$ \\
High school course(s) & $-0.364^{* *}$ & $-0.463^{* *}$ & $\neq-0.268$ \\
& $(0.149)$ & $(0.202)$ & $(0.286)$ \\
College course(s) & 0.337 & 0.403 & 0.033 \\
& $(0.247)$ & $(0.324)$ & $(0.409)$ \\
Classroom environment & -0.284 & $-0.455^{*}$ & -0.174 \\
& $(0.196)$ & $(0.264)$ & $(0.327)$ \\
Perceived level of math required to & $-0.593^{* * *}$ & $-0.488^{*}$ & $-0.739^{*}$ \\
major in economicsc & $(0.209)$ & $(0.252)$ & $(0.413)$ \\
Intercept & $-2.963^{*}$ & 0.044 & -3.685 \\
& $(1.648)$ & $(1.967)$ & $(3.283)$ \\
$N$ & 196 & 87 & 109 \\
-2 x log Likelihood Ratio & $131.741^{* * *}$ & $82.356^{* * *}$ & $41.917^{* * *}$ \\
\hline & & & \\
& & &
\end{tabular}

Notes: Standard errors are shown in parentheses. ${ }^{*}\left(* *{ }^{* * *}\right)$ indicates significance at a $10 \%$ $(5 \%, 1 \%)$ level.

a Positive (negative) values indicate above (below) average of peers.

b The importance of these factors was ranked on a scale of 1 to 6 with higher values indicating greater importance.

c Values range from 1 to 6 where $1=$ Algebra II and $6=$ 'more than Linear Algebra'.

The variables related to mathematics are both significant and have the expected signs. Those who rated themselves as being above average compared to their peers at Denison are significantly more likely to major in economics, while those who think that the level of maths required to be an economics major is high are less likely to choose this major. Finally, we also see that those whose mothers are employed in non-traditional occupations are more likely to major in economics.

Particularly interesting are the results in Table 6 that reveal differences between men and women students. A comparison of columns 2 and 3 shows that among male students, conservatives are significantly and substantially more likely to major in economics. Although the coefficient on this variable also has a positive sign for women, it is small and not significant, suggesting that other factors are more important in inducing women students to major in economics. The dummy variable representing 'Career opportunities' is a significant factor for both men and women, but, perhaps surprisingly, the impact of this variable is almost twice as large for female students. Also surprisingly, 'High school courses' and 'Classroom

environment' have a negative and significant effect for men but not women. On the other hand, for women the variable with the largest and most significant coefficient is self-rated mathematical ability, while this variable is not at all significant for men. Not unexpectedly, while in both equations the perception that a high level of maths is required to be an economics major decreases the likelihood of choosing this field, the effect is considerably stronger for women than for men. Finally, although it might be expected that mother's employment does not have a significant effect for male students, we find that this is true for female students as well. However, since this variable was significant in Model 1 that used the whole sample, this lack of significance may be the result of the small sample sizes.

\section{Conclusion}

In this paper we first looked at recent trends in the enrolment of women and men undergraduates in economics. Official data show that the movement of women into economics has been slower than in most other fields. Among the reasons for this may be a mismatch between the policy implications of economics and the political leanings of some students, both male and female. This pilot study was intended to investigate whether this mismatch exists for undergraduates at a small liberal arts college in the mid-western part of the USA. Given the relatively conservative orientation of economics, our hypothesis was that economics may lose some very talented liberal women and men students who are more likely to find their way to fields better suited to their political orientation. We found that political orientation is a significant determinant of male students' decision to major in economics. However, although the data displayed in several tables seems to support the hypothesis that liberal women are less likely to major in economics, regression analyses do not provide statistical confirmation, perhaps because of the small sizes of the sample. We did find that women's decisions appear to be motivated by different factors than are those of men and, interestingly, our results suggest that very capable male students 
may be discouraged from majoring in economics because of their political leanings. While these results may not be generalizable to large Ph.D.-granting institutions or to other countries, they are likely to be applicable to other small liberal arts institutions in the USA, where the greatest percentages of undergraduates major in economics. Moreover, since our data are for one year only, our explanation for the observed trends can be only tentative. Similar research in other countries would be instructive, as would additional research in the USA using larger and longitudinal samples, and samples from a broader range of institutions. Further investigation might provide stronger support for our original hypothesis that political orientation matters in students' (and especially women's) choice of majors.

Appendix: Definitions of variables used in the regression equations

\begin{tabular}{|c|c|c|c|}
\hline Variable & $\begin{array}{l}\text { Wording of } \\
\text { the Question }\end{array}$ & Choices for Answers & Coding \\
\hline $\begin{array}{l}\text { Political } \\
\text { Orientation }\end{array}$ & $\begin{array}{l}\text { How would you } \\
\text { describe your } \\
\text { political views? }\end{array}$ & $\begin{array}{l}\text { Far left } \\
\text { Left } \\
\text { Moderate } \\
\text { Right } \\
\text { Far Right }\end{array}$ & $\begin{array}{l}-2 \\
-1 \\
0 \\
+1 \\
+2\end{array}$ \\
\hline Gender & Gender & $\begin{array}{l}\text { Male } \\
\text { Female }\end{array}$ & $\begin{array}{l}1 \\
0\end{array}$ \\
\hline $\begin{array}{l}\text { Mother in } \\
\text { non-traditional } \\
\text { occupation }\end{array}$ & Mother's occupation & $\begin{array}{l}\text { Actual occupation } \\
\text { was entered }\end{array}$ & $\begin{array}{l}0=\text { teaching, } \\
\text { nursing or } \\
\text { secretarial } \\
\text { occupations } \\
1=\text { any other } \\
\text { occupation }\end{array}$ \\
\hline $\begin{array}{l}\text { Self-rated math } \\
\text { ability }\end{array}$ & $\begin{array}{l}\text { Please rank yourself } \\
\text { against your } \\
\text { Denison peers }\end{array}$ & $\begin{array}{l}\text { Higher than } 90 \% \text { of peers } \\
\text { Above Average } \\
\text { Average } \\
\text { Below Average } \\
\text { Below } 90 \% \text { of peers }\end{array}$ & $\begin{array}{l}+2 \\
+1 \\
0 \\
-1 \\
-2\end{array}$ \\
\hline $\begin{array}{l}\text { Career Options } \\
\text { with that Major }\end{array}$ & $\begin{array}{l}\text { On a scale of } 1-6 \text {, } \\
\text { please indicate how } \\
\text { influential each of the } \\
\text { following is in } \\
\text { choosing a major: }\end{array}$ & $\begin{array}{l}1=\text { Very Influential } \\
6=\text { Not at All Influential }\end{array}$ & $\begin{array}{l}\text { These values } \\
\text { were } \\
\text { recoded so } \\
\text { as to make } \\
\text { the highest } \\
\text { number (6) } \\
\text { correspond } \\
\text { to 'Very } \\
\text { Influential' }\end{array}$ \\
\hline
\end{tabular}

\begin{tabular}{|c|c|c|c|}
\hline Variable & $\begin{array}{l}\text { Wording of } \\
\text { the Question }\end{array}$ & Choices for Answers & Coding \\
\hline $\begin{array}{l}\text { High School } \\
\text { Classes }\end{array}$ & see'Career & Options'(above) & \\
\hline College Classes & see'Career & Options'(above) & \\
\hline $\begin{array}{l}\text { Classroom } \\
\text { Environment }\end{array}$ & see'Career & Options'(above) & \\
\hline $\begin{array}{l}\text { Perceived level } \\
\text { of math required } \\
\text { to major in } \\
\text { economics }\end{array}$ & $\begin{array}{l}\text { Please select the } \\
\text { highest level of math } \\
\text { that you believe is } \\
\text { required to be an } \\
\text { economics major: }\end{array}$ & $\begin{array}{l}\text { Algebra } \\
\text { Geometry } \\
\text { Algebra II } \\
\text { Pre-calculus } \\
\text { Calculus } \\
\text { Calculus II } \\
\text { Linear Algebra } \\
\text { More than Linear Algebra }\end{array}$ & $\begin{array}{l}1 \\
1 \\
1 \\
2 \\
3 \\
4 \\
5 \\
6\end{array}$ \\
\hline
\end{tabular}

Notes

1 As calculated from National Science Foundation data: www.nsf.gov

2 The percentage for liberal arts colleges and universities is much higher than that for undergraduate programs at Ph.D.-granting institutions but has also been falling over the past five years.

3 Since one semester of economics is required for business administration students, and since business administration is a popular field for women in Sweden, women comprise a larger proportion in lower-level courses there.

4 It should be noted that by 2005-06 the percentage of BAs in the social sciences earned by women had increased slightly further to 52.2 while it had declined to 30.5 in economics (U.S. Department of Education).

5 The Duncan Segregation Index $=1 / 2 \Sigma_{j}\left|M_{i}-F_{i}\right|$. This index, developed by Duncan and Duncan (1955), shows the percentage of one group that would have to change in order for the distribution of the two groups to be the same.

6 For instance, some have argued that women do not have the mathematical ability necessary to succeed in economics (e.g. Dynan and Rouse, 1997; Greene, 1997;

Martino and Winner, 1995; Summers, 2005). Yet as noted above, women comprise a larger percentage of undergraduates in mathematics than in economics. Others have suggested that students who expect to have substantial family responsibilities are more likely to select majors that prepare them for careers with greater flexibility (Blakemore and Low, 1984; Daymont and Andrisani, 1984).

7 It is also interesting to note that Berg and Ferber (1983) found that graduate students were more likely to earn a Ph.D. when they got to know faculty of their own sex well.

8 This is particularly true of those who have a high grade-point average.

9 Viz the best selling textbooks in the USA. It is, however, possible that fewer economists will adhere to these doctrinaire views after the economic crisis of the fall of 2008. 
10 In response to a question from a student whether the study of economics tends to make people conservative, Harvard economics professor and textbook author Greg Mankiw replied:'I believe the answer is, to some degree, yes.... There are at least three, related reasons. First, in some cases, students start off with utopian views of public policy, where a benevolent government can fix all problems. One of the first lessons of economics is that life is full of tradeoffs. That insight, completely absorbed, makes many utopian visions less attractive.... Second, some of the striking insights of economics make one more respectful of the market as a mechanism for coordinating a society.... Third, the study of actual public policy makes students recognize that political reality often deviates from their idealistic hopes.... For these three reasons, many students in introductory economics courses become more conservative - or, to be precise, more classically liberal' (Mankiw, 2006).

11 A related issue, beyond the scope of this study, is whether students in general have become more liberal over time and whether this tendency has contributed to the decline in the percentage of undergraduate students majoring in economics.

12 Liberal arts colleges and universities do not have professional or vocational schools that focus on subjects such as business, engineering, journalism, law or medicine. Approximately 30 per cent of all economics majors in the USA over the past 10 years have been women. The percentage at liberal arts colleges has remained 5-10 percentage points above, and the Ph.D.-granting schools, 5-10 points below, that average. Denison's percentage is typical of small liberal arts colleges in general. See Seigfried (2008).

13 As an incentive to respond, students who completed the survey had a chance to win a 20GB iPod in a draw. Those who failed to return surveys might not have done so for a number of reasons, including already having a device similar to that being offered, or feeling too busy to complete the questionnaire. However, there is no reason to think that this group has different political views or that there is a different relationship between their political views and choice of major than for students in our sample.

14 See Bartlett, Kotrlik and Higgins (2001).

15 An under-representation of women implies, of course, a relative over-representation of men. As suggested earlier, investigating the imbalance means analysing either why too few women or relatively too many men are attracted to economics.

16 Students were also asked a series of questions on topics such as gun control, abortion and same-sex marriage that indirectly revealed their political leanings. We generated an index from these answers as a check on their self-reported political orientation and found a high correlation between the two variables.

17 None of the differences between the views of male and female students shown in Table 2 are statistically significant due, we suspect, to the small sample sizes.

18 The Appendix lists all the variables used in the regression equations, the exact wording of each question in the survey, and contains details about the coding of the individual variables.

19 Because, as already mentioned, Denison does not have a major in business, students who at other universities might choose that field may choose to major in economics as the closest alternative.

20 The need for considerable skill in mathematics in economics today is frequently mentioned as a barrier to more women entering economics. However, it should be noted that in 2003-04 women earned 46.0 per cent of BA degrees in 'mathematics and statistics' (Digest of Education Statistics, 2004).
21 See the Appendix for more details about these variables.

22 Clearly what students perceive may not be accurate. However, since their decisions will be based on their perceptions, these perceptions are more important than the actual requirements.

23 A value of zero indicated either that a student's mother was not in the labour force or that her occupation was considered traditionally female. (See the Appendix for additional information about the variables.)

24 Model 1 is based on the assumption that the coefficients on all the variables are equal for men and women and that only the intercept term varies. The test described above determined that this is not a valid assumption. Nevertheless, we ran this regression model as an intellectual exercise.

25 Self-reported data may be biased, but clearly students' perceptions are more important for their decision than actual ability. Due to student confidentiality we were unable to verify the accuracy of students' reports. Students were also asked about their GPA (where the issue of accurate reporting again arises) but they were not asked to differentiate between grades received for maths courses and for those in other courses.

26 An examination of only economics majors showed that juniors were slightly less liberal than were freshmen and that career options were ranked somewhat less important for juniors than for freshmen. However, neither difference was significant.

27 This suggests that the efforts that the Committee on Economic Education of the American Economic Association has made to improve high school economics courses have borne little fruit to date.

\section{References}

Abrams, B.A. and Settle, R.F. (1999) Women's suffrage and the growth of the welfare state, Public Choice, Vol. 100(3-4), pp. 289-300.

Arcidiacono, P. (2004) Ability sorting and the returns to college major, Journal of Econometrics, Vol. 121, pp. 343-375.

Bartlett II, J., Kotrlik, J.W. and Higgins, C.C. (2001) Organizational research: determining appropriate sample size in survey research, Information Technology, Learning, and Performance Journal, Vol. 19(1), pp.43-50.

Berg, H.M. and Ferber, M.A. (1983) Men and women graduate students:Who succeeds and why? Journal of Higher Education, Vol. 54(4), pp.629-648.

Black, D.A., Sanders, S.G. and Taylor, L. (2003) The economic reward for studying economics, Economic Inquiry, Vol.41(3), pp. 365-377.

Blakemore, A.E. and Low, S.A. (1984) Sex differences in occupational selection:The case of college majors, The Review of Economics and Statistics, Vol. 66(1), pp. 157-163.

Colbeck, C.L., Cabrera, A.F. and Terenzini, P.T. (2001) Learning professional confidence: Linking teaching practices, students' self-perceptions, and gender, The Review of Higher Education, Vol.24(2), pp. 173-191.

Daymont, T.N. and Andrisani, P.J. (1984) Job preferences, college major, and the gender gap in earnings, The Journal of Human Resources, Vol. 19(3), pp.408-428.

Digest of Education Statistics (2004) Washington, DC, U.S. Government Printing Office. Duncan, O.D. and Duncan, B. (1955) A methodological analysis of segregation indexes, American Sociological Review, Vol. 20(2), pp. 210-217. 
Dynan, K.E. and Rouse, C.E. (1997) The underrepresentation of women in economics: A study of undergraduate economics students, Journal of Economic Education, Vol. 28(4), pp. 350-367.

Ehrenberg, R.G., Goldhaber, D.D. and Brewer, D.J. (1995) Do teachers' race, gender, and ethnicity matter? Evidence from the National Educational Longitudinal Study of 1988 Industrial and Labor Relations Review, Vol. 48(3), pp. 547-561.

England, P. and Li, S. (2006) Desegregation stalled:The changing gender composition of college majors, 1971-2002, Gender and Society, Vol. 20(5), pp. 657-677.

Feiner, S. (1993) Introductory economics textbooks and the treatment of issues relating to women and minorities, 1984 and 1991, Journal of Economic Education, Vol. 24(2),

pp. $145-162$.

Ferber, M.A. and Brün, M. (2006) Does your legislator's sex matter? Policy Matters Vol. 4(1), pp. 11-15.

Greene, B. (1997) Verbal abilities, gender, and the introductory course: A new look at an old assumption, Journal of Economic Education, Vol. 23(1), pp. 13-29.

Hativa, N. and Birenbaum, M. (2000) Who prefers what? Disciplinary differences in students' preferred approaches to teaching and learning styles, Research in Higher Education, Vol. 41(2), pp. 209-236.

Jensen, E.J. and Owen, A.L. (2001) Pedagogy, gender, and interest in economics, Journal of Economic Education, Vol. 32(4), pp. 323-343.

Jonung, C. and Ståhlberg, A. (2007) The fruits of economics - a treat for women? - on gender balance in the economics profession in Sweden, Working Paper 5/2007, Stockholm: Swedish Institute for Social Research.

Kemmelmeier, M.C., Danielson, C. and Basten, J. (2005) What's in a grade? Academic success and political orientation, Personality and Social Psychology Bulletin, Vol. 31(10), pp. 1386-1399.

Lott, J.R. Jr. and Kenny, L.W. (1999) How dramatically did women's suffrage change the size and scope of government? Journal of Political Economy, Vol. 107(6), pp. 1163-1198. Mankiw, G. (2006) Response to student inquiry, December 19, 2006, retrieved from http://gregmankiw.blogspot.com/

Martino, G. and Winner, E. (1995) Talents and disorders: Relationships among handedness, sex, and college major, Brain and Cognition, Vol. 29, pp. 66-84.

Monteiro, H. and Lopes, A.F. (2007) A benchmarking of the undergraduate economics major in Europe and in the United States, International Review of Economics Education, Vol. 6(2), pp. 9-20.

Philbin, M. and Meier, E. (1995) A survey of gender and learning styles, Sex Roles, Vol. 32(7-8), pp. 485-494.

Porter, S.R. and Umbach, P.D. (2006) College major choice: An analysis of personenvironment fit, Research in Higher Education, Vol. 47(4), pp. 429-449.

Rask, K.N. and Bailey, E.M. (2002) Are faculty role models? Evidence from major choice in an undergraduate institution, Journal of Economic Education, Vol. 33(2), pp. 99-124.

Robb, R.E. and Robb, A.L. (1999) Gender and the study of economics:The role of gender of the instructor, The Journal of Economic Education, Vol. 30(1), pp. 3-19.

Rothstein, D.S. (1995) Do female faculty influence female students' educational and labor market attainments? Industrial and Labor Relations Review, Vol. 48(3), pp. 515-530.
Siegfried, J.J. (2008) Trends in undergraduate economics degrees: 1991-2007, Journal of Economic Education, Vol.39(3), pp. 297-302.

Siegfried, J.J. and Scott, C.E. (1994) Recent trends in undergraduate degrees, Journal of Economic Education, Vol. 25(3), pp. 281-286.

Summers, L.R. (2005) Remarks at the NBER Conference on Diversifying the Science \& Engineering Workforce, Cambridge, MA. Retrieved from

http://www.president.harvard.edu/speeches/nber.html.

Swope, K.J. and Schmitt, P.M. (2006) The performance of economics graduates over the entire curriculum: The determinants of success, Journal of Economic Education. Vol. 37(4) pp. 387-394.

U.S. Department of Education, National Center for Education Statistics, Higher Education General Information Survey (HEGIS), Degrees and other formal awards conferred surveys, 1970-71 through 1985-86; and 1986-87 through 2005-06 Integrated Postsecondary Education Data System, Completions survey (IPEDS-C:87-99) and Fall 2000 through Fall 2006.

Weinberger, C.J. (1999) Mathematical college majors and the gender gap in wages, Industrial Relations, Vol. 38(3), pp.407-413.

Contact details

Carole A. Green

Department of Economics

College of Arts and Sciences

University of South Florida

Tampa, FL 33620

USA

Email: cgreen@coba.usf.edu

Tel: $\quad 00-1 *-865-408-2561$ 